\title{
THE ANNUAL MEETING OF THE SOCIETY
}

In compliance with the request of the Office of Defense Transportation, the scientific program of the forty-ninth Annual Meeting of the American Mathematical Society, which was scheduled for December 28-30, 1942, in New York City, was cancelled. Therefore the Annual Meeting consisted of the meetings of the Council and the Board of Trustees which were held on December 27 and 28, 1942, in New York City, and at which the following members of the Society were present:

C. R. Adams, W. D. Cairns, W. B. Carver, Arnold Dresden, Nelson Dunford, Tomlinson Fort, R. M. Foster, B. P. Gill, Einar Hille, T. R. Hollcroft, E. M. Hull, J. R. Kline, Solomon Lefschetz, W. R. Longley, C. C. MacDuffee, Saunders MacLane, Marston Morse, G. W. Mullins, F. D. Murnaghan, R. G. D. Richardson, J. F. Ritt, J. D. Tamarkin, A. W. Tucker, Warren Weaver, S. S. Wilks, Oscar Zariski.

At the request of the authors, some of the papers submitted for presentation at the Annual Meeting were listed for presentation in person at future meetings of the Society in New York and Chicago. All other papers which had been submitted were read by title at the meeting of the Council; titles and cross references to the abstracts of these papers appear at the end of this report. At the meeting of the Council the Secretary reported that the Gibbs Lecture, scheduled to be delivered by Professor John von Neumann at the 1942 Annual Meeting, has been cancelled indefinitely since, because of war duties, the lecturer is not available.

The Board of Trustees met at 2:00 P.M. on December 27 in the Faculty Club of Columbia University and adjourned to reconvene at 1:00 P.M. on December 28. The meeting of the Council was held at 2:00 P.M. on December 27 in the Faculty Club of Columbia University.

The Secretary announced the election of the following twenty-two persons to membership in the Society:

Professor Albert Vinicio Baez, Wagner College, Staten Island, N.Y.;

Miss Helen P. Beard, Newcomb College, Tulane University;

Mr. Edward Griffith Begle, Yale University;

Dr. Isaiah Benjamin, Montreal, Quebec, Canada;

Mr. Albert Hosmer Bowker, Massachusetts Institute of Technology;

Mr. Paul Brock, Princeton University;

Professor James A. Cooley, University of Tennessee;

Mr. Charles Laurie Dolph, Princeton University;

Mr. Robert Dean Gordon, Douglas Aircraft Company, El Segundo, Calif.;

Dean Richard Wilson Horn, Dayton Y.M.C.A. College;

Mr. Bertram Kelsey Hovey, University of Pittsburgh;

Mr. Leroy M. Kelly, U. S. Coast Guard Academy; 
Dr. Richard Milton Martin, Princeton University;

Dr. Anne Frances O'Neill, Smith College;

Mr. Charles H. Papas, Aircraft Radio Section, U. S. Navy Department, Washington, D.C.;

Mr. Sidney G. Reed, Jr., University of Notre Dame;

Mr. Edward Rosenthall, McGill University;

Mr. Robert Harris Scanlan, Fleetwings, Inc., Bristol, Pa.;

Mr. Peter Treuenfels, Brooklyn, N.Y.;

Mr. John Michael Walsh, University of Notre Dame;

Miss Rae Wyland, Eastman Kodak Company, Rochester, N.Y.;

Mr. Bertram Yood, Bayonne, N.J.

It was reported that the following had been elected as nominees on the Institutional Memberships of the institutions indicated:

Brown University: Dr. Lipman Bers, Messrs. Wilfred Macdonald Kincaid and Elmer Beaumont Tolsted.

University of California at Los Angeles: Messrs. Marshall Elder and Melvin Samuel Henry.

University of Chicago: Mr. Alexander Robert Jacoby, Miss Janet MacDonald, Mr. William S. Massey, Miss Mary Kathryn Toft, Mr. Daniel Zelinsky.

University of Cincinnati: Mr. David Hal Lipsich.

College of the City of New York: Mr. Herman Chernoff.

Columbia University: Messrs. Frederick Bagemihl, Bernard Russell Gelbaum, Pierre Gutmann, Miss Agnes P. Hollo, Miss Louise Wilhelmina Miller, Mr. F. Steinhardt.

Duke University: Miss Eva Ann Pirkle.

University of Illinois: Miss Mary Rosalie Bear, Dr. Theodore Bedrick, Messrs. Harry Edward Cowan, Harman Leon Harter, and Ray Gartner Langebartel, Miss Jewell E. Schubert.

Indiana University: Mr. Evar Dare Nering, Miss Valentina Annette Potor.

Iowa State College: Mr. Theodore Alfonso Bancroft.

State University of Iowa: Miss Winifred Alice Asprey.

Massachusetts Institute of Technology: Messrs. Julian Himely Bigelow, Donald Laurence Thomsen, Jr., and Edward Joseph Zadina.

University of Michigan: Messrs. Lynn Ulfred Albers, Carl Allen Bennett, Leonard Gustave Johnson, and Clarence Francis Stephens.

University of Pennsylvania: Mr. Samuel Isadore Askovitz, Mrs. Ruth Eileen Goodman.

Smith College: Miss Kathleen Ethelwyn Butcher.

Syracuse University: Miss Lucille Kathryn Pinette.

Texas Technological College: Miss Nancy Ann Miller.

University of Virginia: Mr. Marion Kirkland Fort, Jr.

University of Washington: Mr. Worthie Lefler Doyle, Jr., Miss Frances Adelia Owen.

The following appointments by President Marston Morse were reported: as tellers for the 1942 annual election, Professor E. R. Lorch and Dr. W. C. Strodt; as Committee on Arrangements for the 1943 Annual Meeting in Cleveland, Ohio, Professors J. R. Musselman (Chairman), W. L. Ayres, M. G. Boyce, O. E. Brown, W. B. Carver, 
E. H. Clarke, and C. C. Torrance; as new members of the Committees to Select Hour Speakers: for Annual and Summer Meetings, Professor R. L. Wilder (committee now consists of Professors J. R. Kline, Chairman, M. H. Stone, and R. L. Wilder); for Eastern Sectional Meetings, Professor Saunders MacLane (committee now consists of Professors T. R. Hollcroft, Chairman, Salomon Bochner, and Saunders MacLane); for Western Sectional Meetings, Professor R. E. Langer (committee now consists of Professors W. L. Ayres, Chairman, T. H. Hildebrandt, and R. E. Langer); for Far Western Sectional Meetings, Professor W. M. Whyburn (committee now consists of Professors A. D. Michal, Chairman, G. C. Evans, and W. M. Whyburn).

The Secretary reported that the ordinary membership in the Society is now 2528, including 213 nominees of institutional members and 71 life members. There are also 85 institutional members. The total attendance at all meetings in 1942 was 1010 ; the number of papers read was 319; there were 6 hour addresses, 20 symposium addresses, and 4 Colloquium Lectures; the number of members attending at least one meeting was 641 .

At the annual election which closed on December 30, and at which 455 votes were cast, the following officers were elected:

President, Professor M. H. Stone.

Vice-President, Professor L. M. Graves.

Secretary, Professor J. R. Kline.

Associate Secretary, Professor T. R. Hollcroft.

Treasurer, Professor B. P. Gill.

Members of the Editorial Committee of the Bulletin, Professors Saunders MacLane and P. A. Smith.

Member of the Editorial Committee of the Transactions, Professor A. A. Albert.

Members of the Editorial Committee of the Colloquium Publications, Professors A. B. Coble and J. F. Ritt.

Member of the Editorial Committee of Mathematical Reviews, Professor O. E. Neugebauer.

Member of the Editorial Committee of the American Journal of Mathematics, Professor G. D. Birkhoff.

Members-at-large of the Council, Professors R. P. Agnew, E. T. Bell, Richard Courant, E. R. Hedrick, and D. H. Lehmer.

Members of the Board of Trustees, Professors W. R. Longley, Marsston Morse, and G. W. Mullins, Dean R. G. D. Richardson, and Dr. Warren Weaver.

In an appendix to this report are excerpts from the Report of the 
Treasurer for the fiscal year 1942 as verified by the Auditors. A copy of the complete report will be sent, on request, to any member of the Society. The Board of Trustees adopted a budget for 1943 showing authorized expenditures of $\$ 49,400$. This includes an appropriation of $\$ 1,000$ for Mathematical Reviews from the Marion Reilly Fund.

The Librarian reported that the Library of the Society now contains 10,235 volumes of which 7,344 are bound volumes.

The American Journal of Mathematics, which is published jointly by The Johns Hopkins University and the Society, and to which the Society contributes an annual subvention of $\$ 2,500$, printed 772 pages during 1942.

Certain invitations to give hour addresses were announced: Professors R. H. Cameron and Nelson Dunford for the April, 1943, meeting in New York City; Professor A. E. Taylor for the April, 1943, meeting at Stanford University.

On recommendation of the Committee on Places of Meetings (Professor A. B. Coble, Chairman), it was voted to accept the invitation of Rutgers University to hold the 1943 Summer Meeting at that institution. It was also voted to accept the invitation of Hunter College for the April, 1943, meeting in New York City. The Secretary reported that, according to the Office of Defense Transportation, the final decision regarding scientific meetings lies with the officers of the group involved; the officers are requested to weigh the necessity of each meeting against the existing transportation situation.

The Bulletin Editorial Committee reported that Professors J. H. Curtiss and D. H. Lehmer had been appointed Assistant Editors, for a period of three years, replacing Professors J. L. Doob and Morgan Ward. It was also reported that, beginning in January, 1943, invited addresses will be printed in the green issues of the Bulletin.

The Transactions Editorial Committee reported that during the year 1942 it had published 1,192 pages, the largest figure in its history. As a consequence, the heavy backlog of papers has been reduced and the interval between submission and publication has been diminished from fourteen to six or eight months. It was also reported that Professors Richard Brauer, M. S. Knebelman, and J. J. Stoker have been appointed Associate Editors, to replace Professors A. A. Albert, J. L. Synge, and G. T. Whyburn.

On recommendation of the Council, the Board of Trustees set aside a revolving fund for the purpose of publishing the new series of monographs, Mathematical Surveys. It is expected that the first two volumes of this series will appear during the first half of 1943 . These will 
be Rings by Professor Nathan Jacobson and The problem of moments by Professors J. A. Shohat and J. D. Tamarkin.

As a result of discussions concerning the manpower problem confronting the mathematicians, President Stone was authorized and requested to appoint a War Policy Committee to handle all problems which concern the most effective use of mathematicians in the war effort. He was also authorized to appoint a subcommittee to study means for alleviating the serious shortage of teachers of mathematics which will confront colleges and universities upon the inauguration of the Army and Navy programs.

Titles and cross references to the abstracts of papers read at the Council meeting follow below. Mr. Edward Rosenthall was introduced by Professor Gordon Pall.

1. R. P. Agnew : Euler transformations.'(Abstract 49-1-21-t.)

2. R. P. Agnew: On sequences with vanishing even or odd differences. (Abstract 49-1-22-t.)

3. R. F. Arens: Homeomorphism groups of a space. Preliminary report. (Abstract 49-1-89-t.)

4. I. A. Barnett: A note on skew-symmetric kernels. (Abstract 49-1-23-t.)

5. E. F. Beckenbach: The stronger form of Cauchy's integral theorem. (Abstract 49-1-24-t.)

6. Stefan Bergman: A formula for the stream function of compressible fluid flow. (Abstract 49-1-58-t.)

7. G. D. Birkhoff: Measure-preserving transformations of a planar ring without planar periodic points. (Abstract 49-1-90-t.)

8. D. G. Bourgin: On a theorem of Goldstine's. (Abstract 49-1-91-t.)

9. D. G. Bourgin: Quasi norms in linear topological spaces. (Abstract 49-1-92-t.)

10. D. E. Christie: Net homotopy for compacta. (Abstract 49-1-93-t.)

11. R. F. Clippinger: General remarks about the set of products of positive powers of $n$-by- $n$ matrices and the associated manifold. Preliminary report. (Abstract 49-1-26-t.)

12. R. F. Clippinger: Matrix products of matrix powers. Preliminary report. (Abstract 49-1-27-t.)

13. R. F. Clippinger: Mean value theorems for a certain linear matrix differential equation. Preliminary report. (Abstract 49-1-28-t.)

14. I. S. Cohen : Some theorems on local rings. (Abstract 49-1-1-t.)

15. H. S. M. Coxeter: The map-coloring of unorientable surfaces. (Abstract 49-1-94-t.) 
16. J. H. Curtiss: $A$ note on the theory of moment generating functions. (Abstract 49-1-85-t.)

17. John DeCicco: Conformal geometry of second order differential equations. (Abstract 49-1-70-t.)

18. Jesse Douglas: Point transformations and isothermal families of curves. (Abstract 49-1-71-t.)

19. R. M. Foster: On the average resistance of an electrical network. (Abstract 49-1-59-t.)

20. A. H. Fox: Integral representation of the flow of a compressible fluid around a cylinder. (Abstract 49-1-60-t.)

21. P. R. Halmos: On automorphisms of compact groups. I. (Abstract 49-1-3-t.)

22. A. E. Heins: Some remarks on the solution of dual integral equations. I. (Abstract 49-1-63-t.)

23. H. K. Hughes and Cleota G. Fry: Asymptotic developments of certain integral functions. (Abstract 49-1-33-t.)

24. Edward Kasner: Trajectories in a resisting medium. (Abstract 49-1-66-t.)

25. Edward Kasner and John DeCicco: Bi-isothermal systems in pseudo-conformal geometry. (Abstract 49-1-73-t.)

26. Jakob Levitzki: On semi-nilpotent ideals. (Abstract 49-1-6-t.)

27. W. H. Roever: $A$ new formula for the deviation in range of a projectile due to the earth's rotation. (Abstract 49-1-69-t.)

28. W. H. Roever: The axonometric method of representing the points of space on a plane. (Abstract 49-1-78-t.)

29. Edward Rosenthall: Diophantine equations in arbitrary algebraic number fields. (Abstract 49-1-13-t.)

30. Edward Rosenthall: Diophantine equations in biquadratic fields. (Abstract 49-1-14-t.)

31. H. E. Salzer and Abraham Hillman: Exact values of the first 120 factorials. (Abstract 49-1-84-t.)

32. H. M. Schwartz: On sequences of Stieltjes integrals. II. (Abstract 49-1-42-t.)

33. I. M. Sheffer: Note on a linear transformation of "analytic" type. (Abstract 49-1-43-t.)

34. W. S. Snyder: Non-parametric surfaces and inscribed polyhedra. Preliminary report. (Abstract 49-1-44-t.)

35. Otto Szász: On Abel and Lebesgue summability. (Abstract 49-1-46-t.)

36. W. C. Taylor: Asymptotic behavior of the Abel sums of the Laguerre expansion. (Abstract 49-1-47-t.) 
37. W. J. Trjitzinsky: Singular nonlinear integral equations. (Abstract 49-1-48-t.)

38. S. M. Ulam: On equivalence of functions. (Abstract 49-1-49-t.)

39. S. M. Ulam: On the length of curves, the surface area and the isoperimetric problem under a general Minkowski metric. Preliminary report. (Abstract 49-1-81-t.)

40. T. L. Wade: Euclidean concomitants of the triangle. (Abstract 49-1-15-t.)

41. T. L. Wade: On conjugate tensors. (Abstract 49-1-16-t.)

42. T. L. Wade: On the factorization of rank tensors. (Abstract 49-1-17-t.)

43. T. L. Wade and R. H. Bruck: Types of symmetries. (Abstract 49-1-18-t.)

44. A. D. Wallace: On non-alternating transformations. (Abstract 49-1-101-t.)

45. Alexander Weinstein: On a general variational method for the determination of eigenvalues. (Abstract 49-1-51-t.)

46. J. E. Wilkins: Definitely self-conjugate adjoint integral equations. (Abstract 49-1-54-t.)

47. Fumio Yagi: On a certain Stieltjes integral equation. (Abstract 49-1-55-t.)

48. Antoni Zygmund: $A$ property of the zeros of Legendre polynomials. (Abstract 49-1-57-l.)

J. R. KLINE, Secretary 


\section{APPENDIX}

\section{EXCERPTS FROM REPORT OF TREASURER}

December 16, 1942

To the Board of Trustees of the American Mathematical Society

Gentlemen:

I have the honor to submit herewith the report of the Treasurer for the fiscal year ended November 30,1942, in form similar to that for the previous year.

The market value on November 30,1942, of the securities in the Pool was $\$ 12,714.63$ less than book value. This is to be compared with the total amount, $\$ 7,724.46$, held in accounts "Reserve for Investment Losses" and "Profit and Loss on Sale of Securities." The market value on November 30,1942, of securities in General and Restricted Funds was $\$ 1,459.25$ less than book value. Profit on the sale of securities for General and Restricted Funds amounting to $\$ 295.73$ is still being carried as a reserve against losses to these funds.

Income earned by General Fund Investments during the year amounted to $\$ 1,414.34$. This represents a return of $1 \frac{5}{8} \%$ on amounts in savings banks, and approximately $3 \frac{3}{8} \%$ on securities. Investment Income earned by the Pool amounted to $\$ 7,380.12$, representing a return of approximately $4 \frac{1}{2} \%$. Total Investment Income from all sources was thus $\$ 8,794.46$, corresponding to a yield of approximately $4 \%$. This income and yield may be compared with $\$ 8,864.93$ and approximately $4 \frac{3}{8} \%$ for the fiscal year 1941 .

There appears for the first time a record of income from the Estate of Robert Henderson. The terms of Dr. Henderson's will have earlier been reported to the Trustees and to the Society. There also appears the gift of $\$ 100$ from Professor R. C. Archibald for use of the library.

Respectfully submitted, Bennington P. Gill, Treasurer 
BALANCE SHEET

\section{Assets}

GENERAL AND RESTRICTED FUND ASSETS:

$\begin{array}{cc}\text { November } & \text { November } \\ 30,1942 & 30,1941\end{array}$

Cash................................\$19,177.78

Investments...................... $33,470.47$

$\$ 19,380.05$ $28,814.24$

ENDOWMENT AND OTHER NONEXPENDABLE FUND ASSETS

$\$ 52,648.25$

(POOL):

Cash.................................\$1,409.62

Investments. . . . . . . . . . . . . . . . 163,195.68

$\$ 164,605.30$

Total Assets. ..................... \$217,253.55

$\begin{array}{r}\$ 1,156.70 \\ 160,395.09 \\ \hline \$ 161,551.79 \\ \$ 209,746.08 \\ \hline\end{array}$

\section{Liabilities}

GENERAL FundS:

Sinking Fund ...................... $\quad 515.99$

Profit on Sales of Securities. . . . . . . . . . . . . . . 295.73

Surplus......................... 14,201.68

$\$ 15,013.40$

RESTRICTED FUNDS:

Prize Funds and other Special Funds Accumulated Income.........................\$

Income from Henderson Estate. . . . . . . . . . . .

$4,848.52$

$2,275.00$

Reilly Fund Principal................... $3,968.13$

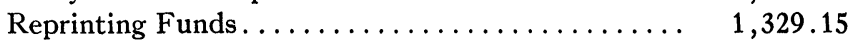

Colloquium.......................... 2,805.04

Mathematical Reviews......................... 16, 184.69

International Congress.................... 6,050.33

Library-R. C. Archibald Gift .............. $\quad 100.00$

Miscellaneous.......................... $\quad 73.99$

$\$ 420.09$ 295.73

$9,048.08$

$\$ 9,763.90$

$\$ 5,613.02$

$3,968.13$

788.86

$5,187.14$

$16,924.45$

$5,943.44$

5.35

$\$ 38,430.39$

$\$ 52,648.25$

$\$ 48,194.29$

ENDOWMENT AND OTHER NONEXPENDABLE FUNDS (POOL):

Endowment Fund Principal. ..............\$60,110.68

Prize Funds and other Special Funds......... 26,935.07

$\$ 60,110.68$

$26,935.07$

$5,304.08$

Life Membership and Subscription Reserve...... 4,835.09

$5,000.00$

$60,000.00$

$2,728.24$

Reserve for Investment Losses. . . . . . . . . . . . . $\quad 3,537.46$

$1,473.72$

Profit on Sales of Securities............... $4,187.00$

$\$ 164,605.30$

$\$ 161,551.79$

Total Liabilities. . . . . . . . . . . . \$217,253.55

$\$ 209,746.08$ 


\section{SUMMARY STATEMENT OF INCOME AND EXPENDITURES}

1941-1942

\begin{tabular}{|c|c|c|c|c|}
\hline \multirow{3}{*}{$\begin{array}{l}\text { GENERAL RECEIPTS } \\
\text { Dues-Ordinary Memberships......... }\end{array}$} & \multicolumn{2}{|c|}{1942} & \multicolumn{2}{|c|}{1941} \\
\hline & Receipts & $\begin{array}{l}\text { Disburse- } \\
\text { ments }\end{array}$ & Receipts & $\begin{array}{l}\text { Disburse- } \\
\text { ments }\end{array}$ \\
\hline & & & & \\
\hline 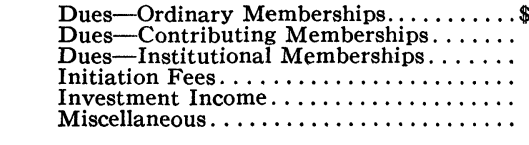 & $\begin{array}{r}15,681.19 \\
1,054.00 \\
7,347.35 \\
665.00 \\
4,643.14 \\
34.73\end{array}$ & & $\begin{array}{r}\$ 14,970.19 \\
1,040.00 \\
6,468.31 \\
515.25 \\
4,147.27 \\
343.15\end{array}$ & \\
\hline \multicolumn{5}{|l|}{ GENERAL DISBURSEMENTS } \\
\hline 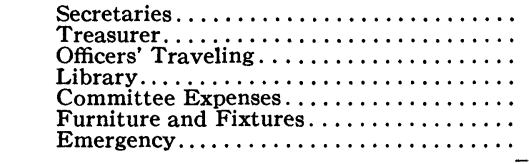 & & $\begin{array}{r}\$ 5,136.86 \\
794.36 \\
643.61 \\
569.95 \\
67.92\end{array}$ & & $\begin{array}{r}\$ 6,091.29 \\
750.00 \\
888.93 \\
824.50 \\
101.04 \\
51.70 \\
277.29 \\
\end{array}$ \\
\hline Total.............................. & $29,425.41$ & $\$ 7,218.41$ & $\$ 27,484.17$ & $\$ 8,984.75$ \\
\hline Excess of General Receipts.......... & $22,207.00$ & & $\$ 18,499.42$ & \\
\hline
\end{tabular}

\section{Publication}

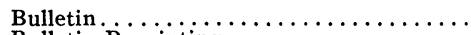

Bulletin Reprinting......................

Transactions
Transactions Reprinting $\ldots \ldots \ldots \ldots \ldots \ldots$

Transaction

$1,673.13$

467.30

$5,787.17$

274.58

$3,814.97$

Mathematical Reviews

$10,809.17$

95.20

$\$ 12,101.37$

$9,373.59$

201.59

$6,197.07$

$11,548.93$

Semicentennial Publications. ............

$2,500.00$

Total

$\$ 22,922.22$

$\$ 41,922.55$

Excess of Cost of Publication......... $\$ 19,000.33$

$\$ 1,755.47 \$ 11,037.14$

$4,816.11 \quad 8,968.10$

$3,437.74 \quad 2,969.55$

$21,467.56 \quad 12,969.22$

129.29

$2,500.00$

$\$ 31,833.79 \$ 38,444.01$

$\$ 6,610.22$

\section{Miscellaneous}

Special Funds (including Congress)......\$ 1,442.39 \$2,100.00

$\begin{array}{ll}\text { Profit on Sales of Securities. . . . . } \ldots \ldots \ldots \ldots & 2,713.28 \\ \text { Income from Henderson Estate...... }\end{array}$

Income from Henderson Estate........

Transactions Reprinting from Surplus.....

Member-Customer Items - not

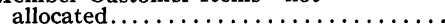

$73.99 \quad 103.86$

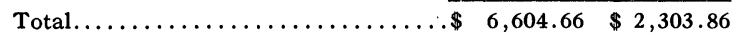

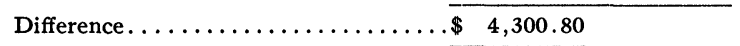

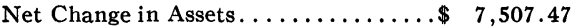

$\$ 9,630.23 \$ 1,000.00$

$8,630.23$

$20,519.43$

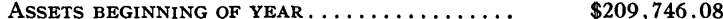

ASSETS END OF YEAR . . . . . . . . . . $\ldots \ldots \ldots . .217,253.55$

$\$ 189,226.65$

$\$ 209,746.08$

${ }^{1}$ Includes $\$ 7,738.78$ principal of gifts. 